\title{
Media Pendidikan Gizi dalam Mengenali dan Mengatur Makanan Cegah Balita Gizi Kurang
}

\author{
Dini Junita ${ }^{1}$, Arnati Wulansari ${ }^{2}$ \\ 1,2 Program Studi Ilmu Gizi, STIKes Baiturrahim Jambi \\ Email:dinijunita.dj.dj@gmail.com
}

Submitted : 07/04/2020

Accepted: 14/04/2020

Published: 16/06/2020

\begin{abstract}
Posyandu is a form of Community-Based Health Efforts (UKBM) which is managed by the community, especially in monitoring nutritional status. Nutrition status monitoring is important because nutrition influences brain development and behavior, work ability and productivity as well as resistance to infectious diseases. Toddlers are an age group that cannot yet manage their own food so parents need supervision, a group of toddlers vulnerable to malnutrition. So that the proper way of Infant and Child Feeding (PMBA) is important to be socialized. The implementation method is in the form of counseling, discussion, practice simulation and pre-post test evaluation. Evaluation monitoring is carried out by looking at indicators of success in the aspect of attendance of targets attending each meeting at the service activities and practices to the target, reflection and feedback from participants as well as PMBA practice behavior can be implemented by the target. After education, there is an increase in the ability of mothers to practice PMBA simulations. It was concluded that the use of media in providing information to mothers is very effective in increasing the ability of mothers in the correct PMBA so that it is expected to reduce nutritional problems in children. A program that is continuous with supervision by health workers and involves cadres in providing information to mothers of toddlers needs to be done.
\end{abstract}

Keywords: education, food manage, preventif, toddler, underweight

\begin{abstract}
Abstrak
Posyandu merupakan salah satu bentuk Upaya Kesehatan Bersumberdaya Masyarakat (UKBM) yang dikelola masyarakat khususnya pemantauan status gizi. Pemantauan status gizi penting dilakukan sebab gizi berpengaruh terhadap perkembangan otak dan perilaku, kemampuan bekerja dan produktifitas serta daya tahan terhadap penyakit infeksi. Balita merupakan kelompok usia yang belum bisa mengatur makan sendiri sehingga perlu pengawasan orang tua, kelompok balita rentan mengalami Gizi kurang. Sehingga cara Pemberian Makanan Bayi dan Anak (PMBA) yang tepat penting untuk disosialisasikan. Metode pelaksanaan berupa penyuluhan, diskusi, simulasi praktek dan evaluasi pre-post tes. Monitoring evaluasi dilakukan dengan melihat Indikator keberhasilan pada aspek kehadiran sasaran menghadiri setiap pertemuan pada kegiatan pengabdian dan praktik kepada sasaran, refleksi dan umpan balik dari peserta serta perilaku praktek PMBA dapat dilaksanakan oleh sasaran. Setelah dilakukan edukasi, terjadi peningkatan kemampuan ibu dalam mempraktekkan simulasi PMBA. Disimpulkan bahwa penggunaan media dalam pemberian informasi kepada ibu sangat efektif guna meningkatkan kemampuan ibu dalam PMBA yang benar sehingga diharapkan dapat mengurangi masalah gizi pada anak. Program yang bersifat kontinyu dengan pengawasan oleh tenaga kesehatan serta melibatkan kader-kader dalam memberi informasi kepada ibu Balita perlu dilakukan.
\end{abstract}

Kata kunci : edukasi, gizi balita, gizi kurang, PMBA

\section{PENDAHULUAN}

Posyandu merupakan salah satu bentuk Upaya Kesehatan Bersumberdaya
Masyarakat (UKBM) yang dikelola diselenggarakan, oleh, untuk dan bersama masyarakat dalam penyelenggaraan pembangunan kesehatan, guna 
$\begin{array}{llr}\text { memberdayakan } & \text { masyarakat } & \text { dan } \\ \text { memberikan } & \text { kemudahan } & \text { kepada }\end{array}$ masyarakat dalam memperoleh pelayanan kesehatan dasar untuk mempercepat penurunan angka kematian ibu dan bayi (Sembiring, 2004). Upaya pengembangan kualitas sumberdaya manusia yang mengoptimalkan potensi tumbuh kembang anak dapat dilaksanakan secara merata apabila sistem pelayanan kesehatan yang berbasis masyarakat seperti posyandu dilakukan secara efektif dan efisien, dan menjangkau semua sasaran yang membutuhkan pelayanan, salah satunya adalah pelayanan tumbuh kembang anak (Depkes RI, 2006).

Kegiatan pemantauan pertumbuhan di Indonesia telah dilaksanakan sejak tahun 1974 melalui penimbangan bulanan diposyandu dengan menggunakan Kartu Menuju Sehat (KMS). KMS memuat kurva pertumbuhan normal anak berdasarkan indeks antropometri berat badan menurut umur dengan penimbangan bulan ini diharapkan gangguan pertumbuhan setiap anak dapat diketahui lebih awal sehingga dapat ditanggulangi secara cepat dan tepat. Pemantauan pertumbuhan perlu ditingkatkan perannya dalam tindak kewaspadaan untuk mencegah memburuknya keadaan gizi balita (Depkes, RI 2005).

Masalah gizi kurang masih tersebar luas di negara-negara berkembang termasuk di Indonesia, masalah yang timbul akibat asupan gizi yang kurang diantaranya Kurang Energi Protein (KEP), Kekurangan Vitamin A (KVA), Gangguan Akibat Kekurangan Yodium (GAKY), dan Anemia. Gizi juga sangat berpengaruh terhadap perkembangan otak dan perilaku, kemampuan bekerja dan produktifitas serta daya tahan terhadap penyakit infeksi (Sulistyoningsih, 2011).

Balita merupakan kelompok usia yang belum bisa mengatur makan sendiri sehingga perlu pengawasan orang tua, kelompok balita mengalami Gizi kurang
(Supariasa et al., 2005). Gizi kurang berdampak langsung terhadap kesakitan dan kematian, gizi kurang juga berdampak terhadap pertumbuhan, perkembangan intelektual dan produktifitas. Anak yang kekurangan gizi pada usia balita, akan tumbuh pendek dan mengalami gangguan pertumbuhan serta perkembangan otak yang berpengaruh pada rendahnya tingkat kecerdasan (Adisasmito, 2008 dalam Dewi FT, 2012).

Masa balita merupakan masa yang sangat penting karena merupakan masa yang kritis dalam upaya menciptakan sumber daya manusia yang berkualitas. Masa kehamilan dan 2 tahun paska kelahiran merupakan masa emas dimana sel-sel otak sedang mengalami pertumbuhan dan perkembangan yang optimal. Menurut UNICEF (1998), anak yang menderita kurang gizi (stunted) berat, mempunyai rata-rata IQ 11 point lebih rendah dibanding rata-rata anak yang tidak stunting (Sukmawati et al., 2018). Oleh karena itu penting didukung oleh pengetahuan dan peran ibu.

Dari data awal yang diperoleh pada tahun 2018 di Puskesmas Simpang Limbur, terdapat Balita gizi kurang berjumlah 13 orang yaitu pada daerah Limbur Merangin 2 orang, Karang Anyar 1 orang dan di Pinang Merah berjumlah 10 orang balita Gizi Kurang. Status gizi pada balita dipengaruhi oleh 2 faktor. Faktor langsung yang mempengaruhi status gizi balita ialah penyakit infeksi dan asupan makan balita, sedangkan faktor tidak langsung yang mempengaruhi status gizi balita diantanya ialah pendidikan, pengetahuan, keterampilan keluarga dan ketahanan pangan (Adisasmito, 2008 dalam Dewi FT, 2012). Jauhnya lokasi mitra dan tingkat pendidikan yang masih menengah ke bawah menjadi penghambat sampainya informasi penting terkait masalah gizi buruk dan penanganannya. Sehingga perlu untuk dilakukan pendidikan kesehatan bagi ibu terutama mengenai cara mengenali status 
gizi anak dan cara Pemberian Makanan Bayi dan Anak (PMBA) yang tepat sehingga terhindar dari gizi kurang. Bahkan di beberapa daerah khususnya daerah terpencil minim informasi bagi ibu, sehingga diperlukan upaya inovatif dalam menyediakan media pendidikan bagi ibu.

\section{TARGET DAN LUARAN}

Kegiatan pengabdian ini memberikan solusi terkait masalah tingginya gizi kurang di wilayah kerja Simpang Limbur yaitu:

1. Pemberian informasi berupa penyuluhan kesehatan mengenai tanda, gejala klinis dan dampak dari gizi kurang pada balita

2. Pemberian informasi dan memprakekkan cara pemberian makanan untuk bayi dan anak yang tepat sesuai usia dan fungsi fisiologis tubuhnya.

3. Memotivasi ibu agar selalu aktif dalam menimbang dan memantau gizi anak dan balita sehingga terhindar dari gizi kurang.

4. Memberikan informasi tata laksana gizi, penanggulangan dan rujukan yag tersedia di pelayanan kesehatan dasar bagi anak dengan masalah gizi, sehingga dapat menginformasikan kepada orang lain dilingkungannya.

Kegiatan pengabdian ini memiliki target khusus yaitu menghasilkan media leaflet dan poster ciri anak mengalami gizi kurang, poster cara pemberian makanan bayi dan anak serta luaran publikasi karya tulis ilmiah dan bahan ajar pada mata kuliah pendidikan gizi dan kesehatan.

\section{METODE PELAKSANAAN}

Kegiatan ini telah dilaksanakan pada bulan September 2018 s/d Januari 2019 berlokasi di Posyandu Unit B1 Desa Pinang Merah, wilayah kerja Puskesmas Simpang Limbur Kabupaten Merangin. yaitu:
1) Menciptakan leaflet dan modul yang efektif dalam menyampaikan pesan cara mengenali anak gizi kurang dan bagaimana cara untuk memberi makan yang tepat kepada anak sehingga terhindar dari gizi kurang.

2) Ibu dapat menerapkan informasi yang diperoleh kepada anak Balita.

Sasaran penyuluhan yang akan dilaksanakan yaitu seluruh ibu yang memiliki anak bayi atau balita usia 6-59 bulan yang mengikuti kegiatan posyandu di Unit B1 Desa Pinang Merah sebanyak 20 orang. Adapun kontribusi sasaran dalam pengabdian masyarakat ini adalah:

1) Menjadi peserta kegiatan pengabdian

2) Mengikuti pre dan post test

3) Aktif dalam bertanya serta menjawab dan mempraktekkan saat simulasi

\section{Pelaksanaan Kegiatan}

Tahapan pelaksanaan kegiatan pengabdian kepada masyarakat ini adalah sebagai berikut:

\section{Persiapan}

a) Menyusun proposal kegiatan pengabdian kepada masyarakat.

b) Menyiapkan poster dan leaflet deteksi ciri anak gizi kurang, pemberian makanan bayi dan anak yang tepat.

c) Menyiapkan materi presentasi manfaat deteksi ciri anak gizi kurang, pemberian makanan bayi dan anak yang tepat.

d) Menyiapkan lembar pre-test dan post test tentang pengetahuan terkait deteksi ciri anak gizi kurang, pemberian makanan bayi dan anak yang tepat.

\section{Pelaksanaan Kegiatan}

a) Perkenalan antara tim pengabdian kepada masyarakat dengan sasaran

b) Penjelasan kegiatan yang akan dilakukan dalam melibatkan sasaran

c) Melaksanakan penyampaian pesan melalui media poster dan leafleat. 
d) Memberikan stimulasi dan motivasi pada ibu untuk peduli dan memperhatikan asupan gizi Balita

e) Memberikan lembar post-test

f) Penutupan

\section{Monitoring dan Evaluasi}

Monitoring dan evaluasi (Monev) dilakukan dengan teknik wawancara dan observasi langsung kepada sasaran. Cakupan Monev dalam kegiatan ini meliputi empat aspsek, yaitu sebagai berikut:

\section{1) Monev Perencanaan}

Pada aspek ini tim akan mengevaluasi kondisi mitra, tujuan program, permasalahan dan pemacahan masalah mitra, isi materi dan praktik kegiatan, media/ alat yang digunakan, sasaran dalam kegiatan pengabdian, waktu pelaksanaan evaluasi (berapa lama, dan kapan evaluasi dilaksanakan), sarana dan prasaran, dan dana yang digunakan.

\section{2) Monev Pelaksanaan Kegiatan}

Indikator keberhasilan pada aspek ini adalah:
a. Sebanyak 90-100\% sasaran menghadiri setiap pertemuan pada kegiatan pengabdian.
b. Kemampuan tim dalam menyampaikan materi dan praktik kepada sasaran.
c. Refleksi dan umpan balik dari peserta kegiatan.
d. Perilaku pemberian makanan bayi dan anak dapat dilaksanakan oleh sasaran.

\section{HASIL DAN PEMBAHASAN}

1. Gambaran Umum Lokasi Pengabdian

Posyandu Unit B1 terletak di Desa Pinang Merah, Kecamatan Pamenang Barat, Kabupaten Merangin, Provinsi Jambi. Dari data awal yang diperoleh pada tahun 2018 di Puskesmas Simpang Limbur, terdapat Balita gizi kurang berjumlah 13 orang yaitu pada daerah Limbur Merangin 2 orang, Karang Anyar 1 orang dan di Pinang Merah berjumlah 10 orang balita Gizi Kurang. Lokasi mitra dan tingkat pendidikan masyarakat yang masih menengah ke bawah diduga menjadi penghambat sampainya informasi penting terkait masalah gizi buruk dan penanganannya.

2. Pelaksanaan Kegiatan

Sasaran dalam kegiatan ini adalah seluruh ibu balita di Posyandu Unit B1 Desa Pinang Merah,berjumlah 20 orang. Pada pelaksanaannya semua ibu menghadiri kegiatan sampai selesai sehingga capaian sasaran dalam kegiatan ini $100 \%$. Kegiatan ini didampingi oleh kader posyandu dan Bidan Desa sehingga diharapkan pendamping tersebut dapat mentransformasikan ilmu yang disampaikan serta memotivasi ibu untuk memberikan perhatian kepada anak khususnya mengenai status gizi dan asupan makannya secara berkesinambungan.

Sebelum diedukasi mengenai materi gizi kurang dan penatalaksanaannya,ibu balita diberikan soal pre-test untuk mengukur pengetahuan awal sebelum diberikan penyuluhan. Setelah dilakukan penyuluhan, sasaran diberikan soal post-test untuk mengukur pengetahuan sasaran setelah diberikan penyuluhan.

Selain itu, pada pelaksanaan tim pengabdian juga mempraktikkan cara mengenali anak gizi kurang dan praktek pemberian makanan yang tepat bagi bayi dan anak.

3. Hasil Kegiatan

Berdasarkan hasil focus grup diskusi para kader memahami cara mengenali anak gizi kurang dan cara penatalaksanaanya. Memahami isi materi, leaflet dan poster yang diberikan sehingga diharapkan mampu menggunakannya untuk kegiatan selanjutnya.

Kegiatan pengabdian diikuti oleh 20 ibu balita. Selanjutnya saat pelaksanaan pemberian edukasi, Ibu mengikuti kegiatan 
penyuluhan sampai selesai. Pemateri menyampaikan informasi dengan lancar, menggunakan media yang sudah disiapkan dengan baik. Peserta antusias terhadap materi penyuluhan dan terlibat langsung dalam kegiatan penyuluhan (diskusi).

Seluruh kegiatan implementasi yang telah dilaksanakan, dapat di evaluasi bahwa kegiatan tersebut berjalan dengan cukup baik, mulai dari penyampaian materi pada peserta kegiatan, selama penyampaian materi itu sendiri peserta menyimak dengan baik. Penyampaian pemberian pretest dan postest, dilanjutkan dengan sesi tanya jawab dan pemberian hadiah (Reward) kepada ibu-ibu yang aktif dalam menjawab pertanyaan, dan peserta mampu menjelaskan dan memahami materi yang telah disampaikan.

Berikut adalah contoh media sederhana yang digunakan dalam pengabdian masyarakat ini :

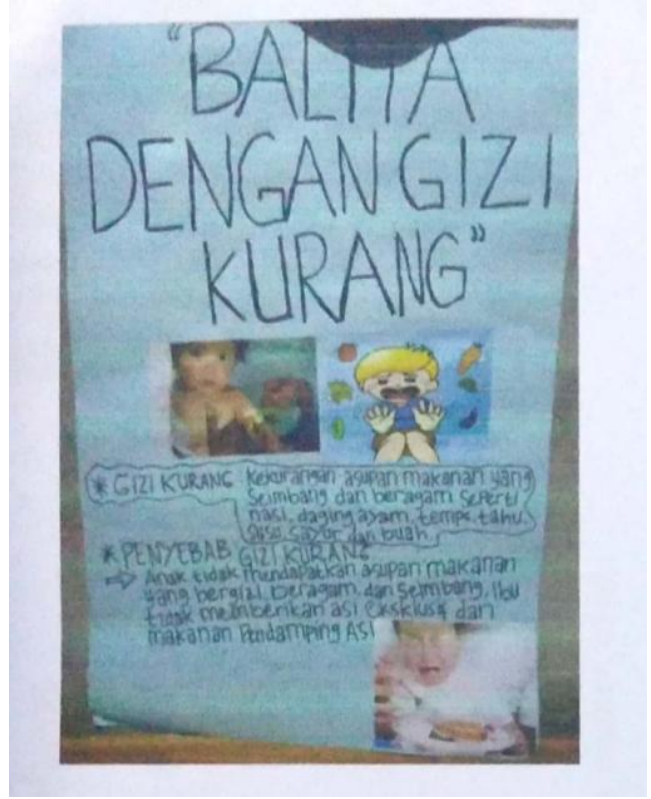

Gambar 1. Poster mengenali Balita gizi kurang

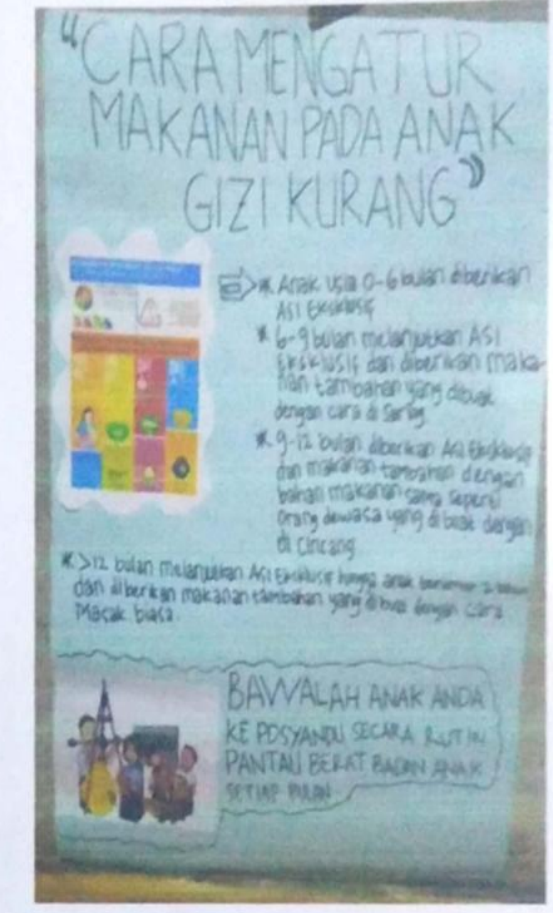

Gambar 2. Pengaturan PMBA Balita

1. Evaluasi struktur

a. Ibu mengikuti kegiatan penyuluhan sampai selesai

b. Pemateri menyampaikan informasi dengan lancar, menggunakan media yang sudah disiapkan dengan baik

2. Evaluasi proses

a. Ibu antusias terhadap materi penyuluhan

b. Ibu terlibat langsung dalam kegiatan penyuluhan (diskusi)

3. Evaluasi hasil

a. Terjadi peningkatan pengetahuan Ibu balita dalam memahami apa yang dimaksud gizi kurang, penyebab, akibat jika anak mengalami gizi kurang

b. Ibu balita mampu menyebutkan tanda dan gejala gizi kurang dan menyebutkan cara memantau gizi kurang

c. Ibu balita mampu mensimulasikan pengaturan makanan yang tepat pada anak. Praktek pemberian makanan/minuman prelaktal, 
praktek pemberian kolostrum, praktek pemberian ASI, praktek pemberian MP-ASI dapat status gizi balita.

\section{KESIMPULAN DAN SARAN}

\section{Kesimpulan}

Meskipun tidak sampai melihat pada implementasi di kehidupan sehari- hari. Namun dapat disimpulkan bahwa pemberian informasi kepada ibu dapat dilakukan dengan media sederhana. Hal ini sangat efektif guna meningkatkan pengetahuan ibu dalam pemberian makanan yang tepat bagi anak yang merupakan bagian penting dalam mengatasi masalah gizi pada anak.

\section{Saran}

Diperlukan program kegiatan yang bersifat kontinyu guna mengawasi kemampuan ibu dalam memberikan makanan bagi anak. Serta perlu pengawasan dari pusat pelayanan dan tenaga kesehatan agar melibatkan kader-kader dalam memberi informasi kepada ibu Balita.

\section{UCAPAN TERIMAKASIH}

Pengabdi mengucapkan terimakasih kepada STIKes Baiturrahim Jambi atas dukungan moril serta materi yang bersumber dari dana pengabdian internal STIKBA sehingga kegiatan ini dapat terlaksana dengan baik.

\section{DAFTAR PUSTAKA}

[Depkes RI]. 2005. Revitalisasi posyandu direktorat kesehatan komunitas. Jakarta.

[Depkes RI]. 2006. Pedoman Umum Pengolahan Posyandu. Jakarta.

Dewi FK. 2012. Perbedaan Perkembangan Motorik Halus Antara Balita Stunting dan Non Stunting di Kelurahan Kartasura Kecamatan Kartasura Kabupaten Sukoharjo [Skripsi]. Fakultas Ilmu Kesehatan Universitas Muhammadiyah Surakarta.
Kardjati. 1985. Pola makan dan status gizi balita. Jakarta: EGC.

Sembiring. 2004. Posyandu sebagai saran peran serta masyarakat dalam usaha peningkatan kesehatan masyarakat. Bagian kependudukan dan biostatistik. Universitas Sumatra Utara: Medan.

Sukmawati, Hendrayati, Chaerunnimah, Nurhumaira. 2018. Status Gizi Ibu Saat Hamil, Berat Badan Lahir Bayi Dengan Stunting Pada Balita Usia 0636 Bulan Di Puskesmas Bontoa. Media Gizi Pangan. Doi: 10.32382/mgp.v25i1.55.

Sulistyoningsih H. 2011. Gizi untuk Kesehatan Ibu dan Anak. Yogyakarta (ID) : Graha Ilmu.

Supariasa, Bakri, Ibnu Fajar. 2005. Penilaian Status Gizi. Jakarta : EGC. 